4. Мельник С.M. Іншомовна лексика як джерело лексичних інновацій у художній прозі кінця XX - початку XXI століття. Збірник наукових праць Лінгвістика. Луганськ : ДЗ ЛНУ імені Тараса Шевченка, 2010. № 2(20). C. 186-193.

5. Черник М.В. Лексико-семантичні засоби вираження мистецьких реалій в англомовних художніх текстах. Нова фрілологія. Збірник наукових праць. Запоріжжя : ЗНУ, 2017. № 70. С. 219-224.

6. Koprince S. Words from the Basement: Markus Zusak's The Book Thief. Notes on Contemporary Literature. 2011. № 41(1). URL : https://www.questia.com/read/1G1-255494819/ words-from-the-basement-markus-zusak-s-the-book-thief.

7. Oddo J. Intertextuality and the 24-Hour News Cycle : A Day in the Rhetorical Life of Colin Powell's U.N. Address. East Lansing, MI : Michigan State University Press, 2014. P. 132-133.

8. Zusak M. The Book Thief. Uxbridge Road, London - BLACK SWAN, 2007. 389 p.

\title{
LINGUOPRAGMATIC ASPECTS OF THE PROCESS OF CONSTRUCTING LEXICAL INNOVATIONS IN MODERN ENGLISH MEDIA DISCOURSE
}

\section{ЛІНГВОПРАГМАТИЧНІ АСПЕКТИ ПРОЦЕСІВ ТВОРЕННЯ ЛЕКСИЧНИХ ІННОВАЦІЙ У СУЧАСНОМУ АНГЛОМОВНОМУ МЕДІЙНОМУ ДИСКУРСІ}

\author{
Chumak L.M., \\ orcid.org/0000-0001-6631-3403 \\ Candidate of Philological Sciences, \\ Senior Lecturer of the Department of the English Language \\ Zhytomyr Ivan Franko State University
}

In the article a structural-semantic analysis of lexical innovations was carried out on the basis of the texts from Modern English media discourse, which allowed to distinguish two types of word-formation models: the non-combined and the combined ones. The process of constructing lexical derivatives by non-combined models is represented by morphological models and the ones of shortening. The principle of constructing lexical innovations by combined models is further subdivided into two groups: the first one - the homogenetic, the structure of which is characterized by the combination of the genetically related elements and ways of lexical innovations word-formation, and the second one - the heterogenetic, based on the combination of genetically unrelated elements and ways of word-formation accordingly. The role of lexical innovations in the implementation of strategies of organizing Modern English media discourse is considered. The following strategies in the English media discourse: attention drawing, informative-interpretative, evaluative, and appealing to necessities, the implementation of which is provided by lexical innovations, are defined. The strategy of attention drawing to the most important information in the media discourse is realized within tactics of lexical innovation position arrangement in the statemen, and second one - explanation of the phenomena, denoted by the innovation. The informative-interpretative strategy is a means of interpreting events, concepts, phenomena, and features that have appeared recently and are represented by new lexemes, embodied in the tactics of informing and appealing to authority. The evaluative strategy is implemented by establishing the significance of the object of evaluation, denoting the positive or negative features of new phenomena. The strategy of appealing to necessities is realized by lexical innovations in the processes of constructing the events in the media discourse that nominate aspects of an individual's existence - physiological needs, needs in safety, affiliation, reputation, self-actualization.

Key words: lexical innovation, word-formation model, media discourse, strategies, tactics.

У статті на матеріалі сучасного англомовного медійного дискурсу проведено структурно-семантичний аналіз лексичних інновацій, що дозволив виокремити некомбіновані та комбіновані моделі творення нових лексем. Процес творення похідних слів за некомбінованими моделями унаочнено морфологічними та моделями скорочення. Принцип творення лексичних інновацій за комбінованими моделями представлено у двох групах: гомогенних, у структурі яких сполучуються генетично споріднені елементи і способи словотворення, та гетерогенних, що ґрунтуються на поєднанні генетично відмінних елементів та способів словотворення відповідно. Розглянуто роль лексичних інновацій у реалізації стратегій організації англомовного медійного дискурсу. Визначено стратегії і тактики, реалізацію яких забезпечують лексичні інновації: привернення уваги, інформаційно-інтерпретаційна, оцінки, апеляції до потреб індивіда. Привернення уваги до сприйняття найбільш важливої інформації в медійному дискурсі здійснюється за допомогою тактик позиційного розміщення лексичних інновацій у повідомленні та пояснення явища, вираженого інновацією. Інформаційно-інтерпретаційна стратегія є способом інтерпретації подій, понять, явищ та ознак, які з'явилися нещодавно та виражені новими словами, що реалізуються у вигляді тактик інформування та апеляції до авторитетів шляхом залучення популярної в певній сфері суспільства думки. Стратегія оцінки реалізується шляхом встановлення значимості об'єкта оцінки через позначення позитивних чи то негативних властивостей нових 
явищ дійсності. Стратегії апеляції до потреб індивіда розглянуто з позиції використання лексичних інновацій у процесах конструювання подій у сучасному англомовному медійному дискурсі, що позначають потреби людини - фрізіологічні, безпеки, належності, репутації, самоактуалізації.

Ключові слова: лексична інновація, словотвірна модель, медійний дискурс, стратегії, тактики.

Problem Setting. The idea of prevalence of complex mechanisms study in the process of constructing lexical innovations in Modern media discourse has become a prerequisite for analyzing the lexical innovations word-formation models form the point of view of structuralism to the position of a pragmatic character.

Highlighting the previous studies and referring to literature. Linguopragmatic aspect of English lexical innovations has been studied from different points, including the idea of pragmatic marking in narrative discourse [10, p. 54], pragmatic variability of a word [4, c. 14], pragmatic orientation in the dictionary definition of neologisms $[2 ; 3 ; 5 ; 6]$, and linguopragmatic parameters of nationally-marked elements of new lexemes [7;8].

The lexical innovations are considered as lexical units, meanings and variants of the use of words, which refer to new concepts in various spheres of human life (Zhluktenko Yu.O. 1983; Kubriakova E.S. 2002; Zatsnii Yu.A. 2010; Holovko O.M. 2010) and organize the message in the media discourse. As a rule, these units are constructed according to the word-formations models. In its turn, the word-formation model is regarded as the scheme of a typical structure, which can be filled in with different lexical material.

Describing methods. The general scientific tendency of complex investigation of lexical innovations word-formation mechanisms, taking into consideration structural, language and pragmatic factors, determines the purpose of this research. Goal setting involves the development of the following tasks: to determine the lexical innovations structural types, implemented in Modern English media discourse; to outline the prospects of applying linguopragmatic analysis in terms of lexical innovations role in the process of constructing Modern English media discourse and its strategies.

The structural method, within which the distributive, transformational, componential and of immediate constituents analyses were used in the research, helped to single out the word-formation models which construct lexical innovations. Contextual-interpretive method enabled to find out how the analyzed innovations correlate with the relevant referents in the English media discourse. The linguopragmatic method gave a new impulse to research the function of lexical innovations and their structural-semantic content to determine the purpose of new words in the process of organizing Modern English media discourse.
Material. The material of this research is taken from the texts of media discourse, presented with electronic versions of articles from newspapers, magazines and news sites in English as well as lexicographic resources (dictionaries, lexicographic and linguistic publications).

Reporting results. The process of constructing new lexical units, according to the structural types of the existed in the language word-formation models, is determined by specific social needs, mainly of pragmatic nature. Lexical innovations function in a wide variety of fields. Modern English media discourse, as a favourable environment for the process of new words constructing and functioning, forms a global communicative sphere.

The analyzed in the paper lexical innovations are taken from the texts of Modern English media discourse. The new lexemes represent two main word-formation groups according to which they are constructed: the non-combined (1) and the combined (2) types. In the present paper the terms "the non-combined" and "the combined" models are used interchangeably to mean the method of constructing and the constituent elements of the analyzed lexical innovations. The first type is embodied in morphological models and the ones of shortening.

(1). From the point of view of the structure, the lexical innovations of morphological word-formation models, which include affixational derivation, word-composition and blending, appear more frequently (65,2\% samples) in Modern English media discourse. In their turn, the new lexemes of the models of shortening, which are represented by abbreviations, including initial ones, acronyms, and clippings, creolized and elliptical lexical units, appear less (34,8\% samples) in Modern English media discourse.

In the present paper the models of affixational derivation are distributed into prefixational (cybermall / cyberplaza, technoburb, netroots, super-gentrification, hyperbeast, multiracial, polyattentiveness, deshopper, cohabitation, neurotheology) and suffixational (solutionist, capitulator, Brexiteer, drifter, nerddom, waithood, hiving, econosplaining, ableism).

Word-composition models with a stable component - a stem which occurs in the language as a free form, recurring in a series of analogous lexical units, include three structural groups, notably: $\mathrm{N}+\mathrm{N}$ (breadhead, chiphead, datahead, lifecaster / lifestreamer, lifeboat, child line, loveline), Adj. + N (red-collar, 
indigo-collar, acoustic weapons, back-end), $\mathrm{N}+$ Adj. (earth-friendly, environmentally-friendly).

Considered in their structure, lexical innovations, constructed on the basis of blending models, fall into three formula groups: the first one - partial ( civilitary $<$ civil + military, freegan $<$ free + vegan, anniaustere $<$ anniversary + austere, womenom$i c s<$ women + economics), the second - complete (computicate $<$ computer + communicate, militainment $<$ military + entertainment, mox $<$ moving + box, cosmeceutical < cosmetic + pharmaceutical $)$ and the third - haplologistic (chexting (cheating + texting, atrosive (atrocious + corrosive).

The group of lexical innovations constructed due to the mechanism of compression of some information [1, c. 49] actualizes the models of shortening that are further classified into: abbreviations $(S I B<$ systemically important bank, $A Q<\mathbf{A l}$ Qaeda / Al Qa'ida, $U C U(<$ University and College Union, $H N W I<$ high net worth individual, $P W<$ personal worst), initials (BC $<$ Basic Component / Boeing Company / Before Children, Before Christmas, Before Contract), acronyms (wags $<$ the wives and girlfriends of high-profile sportspersons, AFAIR < as far as I remember, STEM $<$ science, technology, engineering, mathematics), final clippings ( $v i d<$ video, met $<$ metastasis), initial clippings (shmen $<$ freshmen, bent $<$ recumbent), mixes clippings (bezzle $<$ embezzlement), medial clippings (triff $<$ terrific), creolized lexical units $(W 3<$ World Wide Web / the Web / WWW, glln $<$ globalization, $G 7<$ Group of Seven, X-pansion) and ellipsis (presale $<$ presale view, bang (big bang).

(2). The principle of constructing lexical innovations, according to the combined word-formation models, is based on the combination of genetically related or divergent elements, and, in their turn, is represented by homogenetic and heterogenetic types appropriately.

The genetic affinity of elements and ways of lexical innovations word-formation include four combined homogenetic models: "Compounding and Affixation" (alpha earner, coolhunter, pet-sitter, financial parenting, information environmentalism, defensive pessimist, multi-channel shopping, disfellowshipping), "Blending and Compounding" (blog book, blogswarm, militainment $<$ (military + entertainment) network / complex / music, globesity (< globe + obesity) challenge / pandemic / hotspot), "Blending and Affixation" (sexter $<$ sex + tex(ting) + -er, procaffinator $<$ procrastinating + caffeine + -or, generican $<$ gene + America + -an, mockrockumentary $<$ mock- + rock + documentary), "Affixation and Affixation" (Eurocrat, technoholic, videophilia, infoganda, biopreneur, infonomics).
The process of matching up the unrelated elements and types of word-formation is represented in two combined heterogenetic models: "Shortening and Affixation" (shoppie < shop assistant, rellies < relatives, brigger < brigadier, lecker / lekker $<$ lecture), "Affixational element of the initial type and Compounding" (e-baby, i-dotter, b-blog, m-voting, p-book, t-commerce).

Discussing findings. Linguopragmatic factors play an important role in the functioning of lexical innovations and their structural-semantic content as their "formation is essentially semantically based" $[9$, p. 192]. The present paper gives an opportunity to see a pragmatically determined rapid growth of new Modern English lexical units. The pragmatic aspect is manifested in the necessity to construct a new lexical unit for a new content that is correlated with the relevant referent. New lexical units implement new content on the basis of the existed in Modern English word-formation models. This pragmatic parameter of a new lexeme formation is based on the principle of analogy.

The second question in this research lies in the attempt to explain the peculiarities of lexical innovations to organize media discourse and to find out the media strategies and tactics, the implementation of which is provided by new lexemes.

There is an axiom that Modern English media provides fertile ground for new lexical units to emerge. Lexical innovations, as the components of media discourse, that construct reality, are used to constitute media message about new realities nascency. In this paper we distinguish the following strategies: attention drawing, informative-interpretative, evaluative, appealing to necessities.

The strategy of attention drawing accounts for the fact that new lexemes indicate the most exceedingly important aspects in a media message. The lexical innovation position arrangement in the statement could be either cataphoric or anaphoric. When the new lexeme is before the explanation of the new phenomena, denoted by the innovation, it corresponds to a dictionary definition as it provides its details of the appropriate referent. The cataphoric organization of the innovation presentation gives the description of a new reality fact in the coming after it context. This position arrangement is mostly typical for new terminological units as it gives a logical meaning of a particular idea, given by the lexeme: Unix keeps 3 timestamps for each file: mtime, ctime, and atime. Most people seem to understand atime (access time), it is when the file was last read. There does seem to be some confusion between mtime and ctime though. Ctime is the in ode 
change time while mtime is the file modification time. (Reference, Tech, March 18, 2010). The mentioned above lexical innovations represent the combined heterogenic model "Affixational element of the initial type and Compounding".

In the next example of the attention drawing strategy in the media message, the innovation streetism of non-combined morphological model of derivational affixation is arranged at the end of the statement. The anaphoric organization of the innovation presentation creates a sense of a thorough insight into the new phenomena, helping the reader to come to the conclusion denoted by the new word. In the analyzed media message its author uses also the tactic of explanation of the phenomena, carried out with the help of the commentary technique, when the additional information attracts the reader's attention to the new word: Uncontrolled pregnancies outside the marriage circle have led to a flood of births, with the mothers unable to trace the men responsible. The result is what has come to be known in Ghanaian parlance as "streetism". (Ghanaian Chronicle (Accra, Ghana), Sept. 13, 2004).

The informative-interpretative strategy is embodied by lexical innovations that inform about recently appeared concepts, naming people by their activities, distinctive characteristics, objects, etc., and interpret events, facts of life, the actual state of facts, results of various scientific researches, providing a point of view of officials, experts, specialists. In the following media message the lexical innovation of the combined homogenetic model "Compounding and Affixation" acoustic snooping - "stealing typed data by decoding the sounds of the keyboard strokes" [11] is represented on the basis of the tactics of informing and appealing to authority: Researchers at the University of California, Berkeley, have discovered that by making highly accurate recordings of computer keyboard strokes, they were able to reconstruct e-mail messages, retrieve data entered into a report, and recreate passwords typed into a secured Web site, essentially overhearing Internet conversations, says The Futurist magazine. They used audio gear available over-the-counter. "The message from this study is that there is no easy escape from this acoustic snooping" contends Doug Tygar, one of the researchers. (The Globe and Mail, December 27, 2005).

The strategy of evaluation is embodied in the tactics of shaping either positive or negative evaluation. For example, the usage of the affixational element-friendly as the structural component in the series of the lexical innovations, constructed according to the morpholog- ical model of $N+$ Adj(friendly), represent approval, consent, positive experience: Food items, in specific, tend to be considerably superior when they are ecofriendly, and you'll find that obtaining them may benefit you in quite a few methods. (Environmental issue community, November 28, 2011).

The negative evaluation, on the contrary, as with the innovation sexter of the combined homogenetic model "Blending + Affixation" in the following media message, is associated with the indication of despondency to success, to neglect, contempt, conviction, irony, sarcasm: Law enforcement has shown little ability to punish, or interest in punishing, the people who distribute teen sexts, or who violate teen girls' trust for the purpose of humiliating or damaging them. Courts often assume that any sexual image will automatically and always be distributed. The crime is taking the image in the first place, and naively, stupidly assuming it will remain private. Hasinoff points to one case, in which a judge convicted a teen sexter whose images were never distributed on the grounds that she should have known that her boyfriend would eventually send them around. (Reason magazine, April 18, 2015).

The strategy of appealing to necessities is embodied with the help of lexical innovations which nominate aspects of new phenomena that meet the needs of an individual's existence, referring to the needs in safety, as with the example of the innovation jihadist (morphological model $N+-i s t$ ) in the next media message: The EU decision to lift Syrian oil sanctions to aid the opposition has accelerated a scramble for control over wells and pipelines in rebel-held areas and helped consolidate the grip of jihadist groups over the country's key resources. (The Guardian, May 19, 2013).

The lexeme datasexual, constructed by the wordcomposition model $N($ data $)+N$, demonstrates the tactic of appealing to the needs of an individual's existence, together with the tactics of self-actualization and sensual satisfaction: Here is a collection of people who record and track their everyday lives online, and then analyze and quantify their existence, from tooth brushing to reading to fecal contents. These "datasexuals" now have a social movement, of a sort, which they call the "Quantified Self" movement. (Whimsley, March 9, 2013). In the analyzed media message the new lexeme datasexual is used to denote people by their social affiliation, also the events of social, active personal fulfillment and the involvement of the participants of events to types of their everyday activity.

Conclusions and Perspectives. The present study of the lexical innovations structure, language 
and pragmatics is only a small sample of the coinages based on the analysed non-combined and combined word-formation models, used in Modern English media discourse. Media is an amazing source of data for any linguistic research area. It reflects the dynamic changes occurring in the language. An increasing number of lexical innovations, customary found in Modern English media to represent the totality of facts in various spheres of life, are used to organize the message in the media discourse.

These findings provide the following insights for further research: to establish the cognitive mechanisms in the process of forming lexical innovations involving a particular word-formation model; to determine the role of lexical innovations in organization of other types of discourse.

\title{
REFERENCES:
}

1. Алексеев Д.И. Графические сокращения и слова-аббревиатуры. Развитие современного русского языка. Москва, 1963. С. 49-145.

2. Головко О.М. Лінгвальна актуалізація вимірів антропного буття (на матеріалі інновацій англійської мови) : дис. ... кандидата філол. наук : 10.02.04. Херсон, 2010. 200 с.

3. Жлуктенко Ю.А. Английские неологизмы : монография / отв. ред. Ю.А. Жлуктенко и др. Киев : Наукова думка, 1983. $172 \mathrm{c}$.

4. Заботкина В.И. Неологизмы в современном английском языке. Калининград , 1982. С. 12-14.

5. Зацний Ю.А., Янков А.В. Нова розмовна лексика і фразеологія: Англо-український словник. Вінниця : Нова Книга, 2010. 224 с.

6. Кубрякова Е.С. Неология: проблемы и перспективы. Проблемы английской неологии : материалы научной конференции (29 января 2002 г.). Москва : МГЛУ, 2002. С. 5-11.

7. Маслова А.Ю. Введение в прагмалингвистику : учеб. пособие. Москва : Флинта : Наука, 2010. 152 с.

8. Сусов И.П. Лингвистическая прагматика. Москва : Восток-Запад, 2006. 200 с.

9. Bolozky S. Measuring Productivity in Word Formation: the Case of Israeli Hebrew. Leiden; Boston : Brill, 1999. 253 p.

10. Katz J.J. Propositional Structure and Illocutionary Force. A study of the Contribution of Sentence Meaning to Speech Acts / J. J. Katz. N.Y. : Crowell, 1977. 249 p.

11. WordSpy. URL : http://www.wordspy.com/.

УДК 81'344.4

DOI https://doi.org/10.32782/tps2663-4880/2020.13-2.37

\section{ФОНЕТИЧНА СТРУКТУРА ФРАНЦУЗЬКИХ ЗАПОЗИЧЕНЬ В АСПЕКТІ БРИТАНСЬКОЇ ВИМОВНОЇ НОРМИ}

\section{PHONETIC STRUCTURE OF FRENCH BORROWINGS IN BRITISH PRONUNCIATION NORM}

\author{
Шишко А.В., \\ orcid.org /0000-0003-3932-1541 \\ кандидат педагогічних наук, дочент, \\ дочент кафедри перекладу \\ Кременчуцького національного університету імені Михайла Остроградського
}

Комар Л.В.,

orcid.org /0000-0003-1961-3221 старший викладач кафедри міжнародних економічних відносин, адміністрування та мовної підготовки Філї «Кременчуцький інститут ВНЗ «Університет імені Альфреда Нобеля»

\footnotetext{
Стаття присвячена дослідженню фонемних та акцентних структур пізніх французьких запозичень у британській вимовній нормі. Актуальність вивчення цієї проблеми зумовлена потребами пізнання закономірностей фронологічного нормування іншомовних слів в аспекті вимовної норми. У ході дослідження визначено місце пізніх французьких запозичень у словниковому складі англійської мови, надано загальну характеристику фонемних та акцентних структур франкомовних слів у британській вимовній нормі, розглянуто специфічні риси фонетичних структур французьких запозичень, які впливають на їхню фонологічну асиміляцію у британському вимовному варіанті.

Встановлено, що велика кількість франкомовних слів відбиває фонеми, або фонотактичні особливості, які не властиві англійській мові. Традиційно такий вид запозичень називається галліцизмами, які асоціюються зі словами місцевого колориту, а також вони позначають характерні особливості, звичаї, спосіб мислення, які притаманні
} 